\title{
Determination of durability of Metakaolin Blend High Grade Concrete by using Water Permeability Test
}

\author{
${ }^{1}$ Dr.Jadhao Pradip D, ${ }^{2}$ Shelorkar Ajay P. \\ ${ }^{I}$ (Professor \& Head, Department of Civil Engineering, K.K.Wagh Institute of Engineering Education \& \\ Research,Nashik / University of Pune, India ) \\ ${ }^{2}$ (Assistant Professor, Department of Civil Engineering, N.D.M.V.P.S.K.B.T.College of Engineering,Nashik / \\ University of Pune, India)
}

\begin{abstract}
The main objective of the study was to investigate the properties of binary blends metakaolin. A suitable mix design of High Grade Concrete (HGC) has been developed using artificial sand (VSI Sand).The engineering properties of both fresh and hardened HGC were studied. The properties investigated include water penetration and compressive strength. Permeability of concrete affects the durability of concrete. The permeability of concrete is mainly affected by pore structure system of concrete. The penetration of water was studied using the water permeability test method, in accordance with the procedure. The effect of the amount of pozzolanic content on the observed trends was studied. It was established that binary mixtures could differ significantly in both their fresh and hardened properties. Significantly, the binary blends incorporating metakaoline were found to have greater improvement in strength and water penetrability.
\end{abstract}

Keywords -binary blends, metakaoline, permeability test, artificial sand (VSI Sand), compressive strength, HGC (High grade concrete), HRM (High Reactive Metakaolin).

\section{INTRODUCTION}

The introduction of the plain cement concrete by using Portland cement may suffer a variety of durability problems depending on the source of cement, the type of aggregates and the environmental exposure conditions. Corrosion of reinforced steel bars in concrete is the major cause of early concrete deterioration. ${ }^{[1]}$ This form of deterioration is primarily induced by penetration of water in into pores of concrete. The ingressing water penetration tends to depassivate the oxide film that normally protects steel from corrosion. It is well known that the durability of the structures decreases dramatically when concrete is made with inadequate check on penetrability of deleterious substances or if the concrete cover to reinforcement is inadequate. It is, therefore, important to discourage the penetration of free chloride-ions in order to prevent the corrosion of reinforcing bars embedded in concrete Permeability of concrete may be reduced through a variety of methods but the easiest of this is by making a low water/binder ratio mixtures. When incorporated in binary blends, pozzolanic materials are known to react with calcium hydroxide $(\mathrm{CH})$, which is a product of cement hydration, to produce additional reaction products, such as calcium silicate hydrate $(\mathrm{C}-\mathrm{S}-\mathrm{H})^{[2]}$ which improves strength and porosity. This is in turn leads to a more impermeable and durable high grade concrete. High grade concrete is a type of high performance concrete with a specified compressive strength of $40 \mathrm{MPa}$ or greater. ${ }^{[6]}$

\subsection{Cement}

\section{MATERIALS USED}

Ordinary Portland cement of 53 grades available in local market is used in the investigation. The cement used has been tested for various proportions as per IS 4031-1988 and found to be confirming to various specifications of as per IS 12269-1987. The specific gravity was 2.96 and fineness was $3200 \mathrm{~cm}^{2} / \mathrm{gm}$.

2.2 Coarse aggregate

Crushed stone angular metal of $10 \mathrm{~mm} \& 20 \mathrm{~mm}$ size from a local source was used as coarse aggregate. The specific gravity of 2.98 and fineness modulus 2.55 was found to be confirming to various specifications of as per IS: $383-1970^{[7]}$

\subsection{Fine aggregate}

Artificial sand (VSI Sand) was used as fine aggregate. The specific gravity of 2.98 and fineness modulus 3.05 was used in the investigation. Artificial sand was obtained from stone crushing plant (vertical shaft impact). It was found to be confirming to various specifications of as per IS: $383-1970^{[7]}$

\subsection{High Reactive Metakaolin(HRM)}

Metakaolin which is obtained by the calcinations of pure or refined Kaolinite clay at a temperature of between $650{ }^{\circ} \mathrm{C}$ and $8500^{\circ} \mathrm{C},{ }^{[8]}$ followed by grinding to achieve a fineness of $700-900 \mathrm{~m}^{2} / \mathrm{kg}$ exhibits high pozzolanicity. ${ }^{[6]}$ When used in concrete it will fill the void space between cement particles resulting in a more 
impermeable concrete $^{[3]}$. The metakaoline used in this study is Metacem of grade 85-C. HRM is a highly reactive pozzolan that reacts with calcium hydroxide produced from free lime during the hydration of metakaoline cement, forming calcium silicate and alumino silicate hydrates. These cementitious products supplement the binding action in concrete. This formulation provides increased density, resulting in reduced porosity and permeability and increased chemical resistance. ${ }^{[2]}$ In many ways, the pozzolanic reaction of HRM is similar to that with fly ash, but with HRM the finer particle size and higher surface area enables the pozzolan to react much faster and more frequently.Metacem- 85 is available in white powder form having large surface area than OPC and its provided by 20 micron company Mumbai. For this experimental work proportions $4 \%$, $6 \% \& 8 \%$ of weight of cement were used for mixing. The HRM conform to IS $456: 2000 .{ }^{[8]}$

\subsection{Properties of Metakaolin}

Metakaolin (MK 85) had 99.9\% particles blain $16 \mu \mathrm{m}$ with a mean particle size of about $3 \mu \mathrm{m}$. The typical physical properties is given in Table 2.1 and typical chemical compositions is given in Table 2.2

\subsubsection{Uses of Metakaoline}

Metakaolin finds usage in many aspects of concrete:

- High performance, high strength,high grade and lightweight concrete.

- Precast concrete for architectural, civil, industrial, and structural purposes.

- Fiber cement and ferrocement products, ceramic product.

- Glass fiber reinforced concrete, Steel crimp fibre reinforced concrete

- Mortars, stuccos, repair material, Swimming pool plasters

- Precast concrete and tiles.

- Dry mix ,render and plastering

- Ready mix concrete

- Floor screeds

- Manufactured repetitive concrete product

- Shotcrete application

\subsubsection{Advantages of using Metakaolin}

- Increased compressive and flexural strengths

- Reduced permeability

- Increased resistance to chemical attack

- Increased durability

- Reduced effects of alkali-silica reactivity (ASR)

- Reduced shrinkage due to particle packing, making concrete denser

- Enhanced workability and finishing of concrete

- Reduced potential for efflorescence

- Improved finishability, colour \& appearance

Table 2.1 Physical properties of Metakaolin (www.metakaolin.com)

\begin{tabular}{|l|l|}
\hline Property & Value \\
\hline Specific gravity & 2.60 \\
\hline Bulk Density $\left(\mathrm{g} / \mathrm{cm}^{3}\right)$ & 0.3 to 0.4 \\
\hline Physical form & Powder \\
\hline Colour & Off-White \\
\hline GE Brightness & $79-82$ \\
\hline$D_{10}$ & $<2.0 \mu \mathrm{m}$ \\
\hline$D_{50}$ & $<4.5 \mu \mathrm{m}$ \\
\hline
\end{tabular}

Table 2.2 Chemical composition of Metakaolin (www.metakaolin.com)

\begin{tabular}{|l|l|}
\hline Types & \% by mass \\
\hline $\mathrm{SiO}_{2}$ & 51.52 \\
\hline $\mathrm{Al}_{2} \mathrm{O}_{3}$ & 40.18 \\
\hline $\mathrm{Fe}_{2} \mathrm{O}_{3}$ & 1.23 \\
\hline $\mathrm{CaO}$ & 2.0 \\
\hline $\mathrm{MgO}$ & 0.12 \\
\hline $\mathrm{K}_{2} \mathrm{O}$ & 0.53 \\
\hline $\mathrm{SO}_{3}$ & 0.0 \\
\hline $\mathrm{TiO}_{2}$ & 2.27 \\
\hline $\mathrm{Na}_{2} \mathrm{O}$ & 0.08 \\
\hline $\mathrm{L} . \mathrm{O} . \mathrm{I}$ & 2.01 \\
\hline
\end{tabular}




\subsection{Admixture}

Viscocrete10R (W) from Sika was used for increasing the workability of concrete mix. The admixture were used by percentage of mass of cement ( $1 \%$ of mass of cement ).The same percentage was adopted for all four mix proportion to maintain the slump during fresh concrete condition.

\subsection{Water}

The water used in preparing the specimen was potable water obtained from drinking water source. Generally water that is suitable for drinking is satisfactory for use in concrete.

\section{Mixture Proportions And SPECIMEN PreParation}

Table 3.1 shows the mixtures used and their compositional contents. The blended mixtures contain different percentages of the cement replacement materials but the proportions for all other materials were constant. For every mixture, 15 cubes ( $150 \times 150 \mathrm{~mm}$ in size), for determination of compressive strength and water permeability of concrete, were casted. The cube specimens were casted according to the specifications in IS: 10086-1982. Compaction was done in two layers by means of a vibrating table. After casting, all specimens were covered with a polythene sheet and placed in a room maintained at a constant temperature of $20^{\circ} \mathrm{C} \pm 2^{\circ} \mathrm{C}$ and $99 \%$ relative humidity. The specimens were de-molded after 24 hours and left in the curing room until they were due for testing. The cube specimens were used for assessing compressive strength and determination of water permeability of concrete.

In the compressive strength test specimen, following abbreviations were used as $\mathrm{CC}$ for control concrete for both test specimens were divided in to set and MK85-(0\%),MK85-(4\%),MK85(6\%) and MK85-(8\%) for $0 \%, 4 \%, 6 \%$ and $8 \%$ replacement of metakaoline by mass of cement respectively.

Table3.2 Various Mix proportion of Metakaolin Blend Concrete

\begin{tabular}{|c|c|c|c|c|c|}
\hline \multirow{2}{*}{ Sr. No } & Material & $\begin{array}{c}\text { MK } \\
(0 \%)\end{array}$ & $\begin{array}{c}\text { MK } \\
(4 \%)\end{array}$ & $\begin{array}{c}\text { MK } \\
(6 \%)\end{array}$ & $\begin{array}{c}\text { MK } \\
(8 \%)\end{array}$ \\
\hline 1 & Ordinary Portland Cement $\left(\mathrm{Kg} / \mathrm{m}^{3}\right)$ & 500 & 480 & 470 & 460 \\
\hline 2 & Metakaolin (Metacem 85$)\left(\mathrm{Kg} / \mathrm{m}^{3}\right)$ & 00 & 20 & 30 & 40 \\
\hline 3 & Artificial Sand $\left(\mathrm{Kg} / \mathrm{m}^{3}\right)$ & 907 & 907 & 907 & 907 \\
\hline 4 & Coarse Aggregate $(20 \mathrm{~mm})\left(\mathrm{Kg} / \mathrm{m}^{3}\right)$ & 614 & 614 & 614 & 614 \\
\hline 5 & Coarse Aggregate $(10 \mathrm{~mm})\left(\mathrm{Kg} / \mathrm{m}^{3}\right)$ & 409 & 409 & 409 & 409 \\
\hline 6 & Water & 145 & 145 & 145 & 145 \\
\hline 7 & Viscocreate $1 \%\left(\mathrm{Kg} / \mathrm{m}^{3}\right)$ & 5 & 5 & 5 & 5 \\
\hline 8 & Water Binder Ratio & 0.29 & 0.29 & 0.29 & 0.29 \\
\hline
\end{tabular}

\section{METHODOLOGY}

\subsection{Compressive Strength Test}

The compressive strength of concrete was determined in accordance with Indian Standards IS: 516 1959 (Reaffirmed 1999) Edition 1.2 (1991-07) ${ }^{[9]}$. This involved applying direct compressive loads to the test specimens in the vertical direction at a constant rate of $150 \mathrm{KN}$ per minute. Tests were conducted after 3, 7, 28, 56 days of curing. The results obtained are shown in Table 4.1

\subsection{Water Permeability Test}

Depth of penetration of water was obtained by DIN 1048 method. The equipment was installed on leveled ground. The compressor for test was of 5 bars capacity. The air dried concrete cubes $(150 \mathrm{~mm})$ were mounted on the table with suitable rubber gaskets below the cubes. The surface was roughened for about 100 $\mathrm{mm}$ diameter with wire brush before placing for test. The M.S.Plate was kept on the cube and the bolt was tightened on the cube. The pressure of 5 bars was maintained for 72 hours. The compressor was switched off and the pressure was released. All the cubes were splitted under concrete testing machine with the help of splitting device provided with equipment and the maximum and minimum water penetration level was observed .The average value was found out as shown in Table 4.2 
Table 4.1 Compressive Strength Result of Metakaolin Blend Concrete

\begin{tabular}{|c|c|c|c|c|c|}
\hline Sr. No & Type & Cube ID & $\begin{array}{l}\text { Cube mass } \\
(\mathrm{kg})\end{array}$ & $\begin{array}{l}\text { Strength } \\
(\mathrm{MPa})\end{array}$ & $\begin{array}{l}\text { Avg. Strength in } \\
\text { MPa }\end{array}$ \\
\hline 1 & \multirow{3}{*}{ C.C. } & $\mathrm{CC} 1$ & 9.10 & 92.00 & \multirow{3}{*}{91.10} \\
\hline 2 & & $\mathrm{CC} 2$ & 9.13 & 91.00 & \\
\hline 3 & & $\mathrm{CC} 3$ & 9.13 & 90.40 & \\
\hline 1 & \multirow{3}{*}{$4 \%$ MK 85} & A54 & 9.13 & 101.00 & \multirow{3}{*}{100.36} \\
\hline 2 & & A55 & 9.12 & 97.73 & \\
\hline 3 & & A56 & 9.10 & 102.35 & \\
\hline 1 & \multirow{3}{*}{$6 \%$ MK 85} & A39 & 8.96 & 104.15 & \multirow{3}{*}{104.11} \\
\hline 2 & & $\mathrm{~A} 40$ & 9.08 & 104.82 & \\
\hline 3 & & A41 & 9.00 & 103.36 & \\
\hline 1 & \multirow{3}{*}{$8 \%$ MK 85} & A18 & 9.05 & 109.20 & \multirow{3}{*}{112.00} \\
\hline 2 & & A19 & 9.04 & 115.00 & \\
\hline 3 & & $\mathrm{~A} 20$ & 9.00 & 112.04 & \\
\hline
\end{tabular}

Table 4.2 Water Permeability of Concrete with percentage variation of MKs5

\begin{tabular}{|c|c|c|c|c|c|}
\hline $\begin{array}{l}\text { Sr. } \\
\text { No }\end{array}$ & Type & $\begin{array}{c}\text { Cube } \\
\text { ID }\end{array}$ & $\begin{array}{c}\text { Age } \\
\text { (Days) }\end{array}$ & $\begin{array}{l}\text { Penetration } \\
\text { Depth } \\
\text { (mm) }\end{array}$ & $\begin{array}{c}\text { Avg. Penetration Depth } \\
\text { ( mm) }\end{array}$ \\
\hline $\mathbf{1}$ & \multirow{3}{*}{ C.C. } & $\mathrm{CCl}$ & 56 & 22 & \multirow{3}{*}{23.00} \\
\hline 2 & & CC2 & 56 & 23 & \\
\hline 3 & & $\mathrm{CC} 3$ & 56 & 24 & \\
\hline I & \multirow{3}{*}{$4 \%$ MK 85} & MK41 & 56 & 10 & \multirow{3}{*}{11.67} \\
\hline 2 & & MK42 & 56 & 12 & \\
\hline 3 & & MIK43 & 56 & 13 & \\
\hline $\mathbf{1}$ & \multirow{3}{*}{$6 \%$ MK 85} & MK61 & 56 & 8 & \multirow{3}{*}{8.67} \\
\hline 2 & & MK62 & 56 & 9 & \\
\hline 3 & & MK63 & 56 & 9 & \\
\hline 1 & \multirow{3}{*}{$8 \%$ MK 85} & MK81 & 56 & 7 & \multirow{3}{*}{6.67} \\
\hline 2 & & MKS2 & 56 & 6 & \\
\hline 3 & & MKS33 & 56 & 7 & \\
\hline
\end{tabular}

\section{RESULTS AND DISCUSSIONS}

\subsection{Effect of Percentage Replacement of Metakaolin on Compressive Strength of HGC:}

The variation of compressive strength of HGC with varying percentage of Metakaolin $(0,4,6$, and $8 \%)$ is shown in Figure 5.1. The compressive strength increases was about $9.23 \mathrm{MPa}$ for $4 \%$ Metakaolin (Metacem85), $12.98 \mathrm{MPa}$ for $6 \%$ Metakaoline (Metacem-85) and $20.87 \mathrm{MPa}$ for $8 \%$ Metakaolin (Metacem-85). The increase in compressive strength due to the addition of Metakaolin (Metacem-85) by weight of cement are 10.13 $\%, 14.24 \%$ and $22.90 \%$ respectively as compared to compressive strength of control concrete (CC) specimen of HGC .

\subsection{Effect of percentage replacement of Metakaolin on water permeability of HGC:}

Fig. 5.2 shows the variation of depth of penetration of water in HGC with Metakaolin(Metacem85)content variation from $4 \%, 6 \%$ and $8 \%$. The depth of penetration reduces by $11.33 \mathrm{~mm}, 14.33 \mathrm{~mm}$ and 16.33 $\mathrm{mm}$ respectively as against for the increase of Metakaolin (Metacem-85) content by 4\%, 6\%and $8 \%$ content respectively. The decrease in depth of penetration with the increase in Metakaolin(Metacem-85)content due to filling effect of the Metakaolin(Metacem-85). The percentage reduction in the depth of water penetration comparison with control concrete specimen (cc) are as $49.26 \%, 62.30 \%$ and $71.00 \%$ respectively as against for $4 \%, 6 \%$ and $8 \%$ Metakaolin(Metacem-85)content .

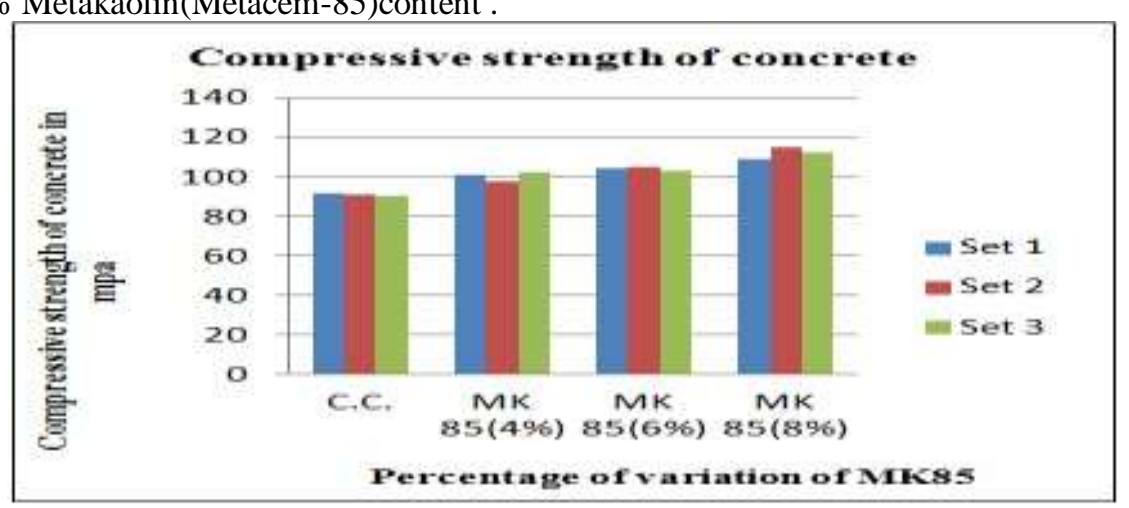

Fig. 5.1 Compressive Strength of concrete with percentage variation of Metacem 85 


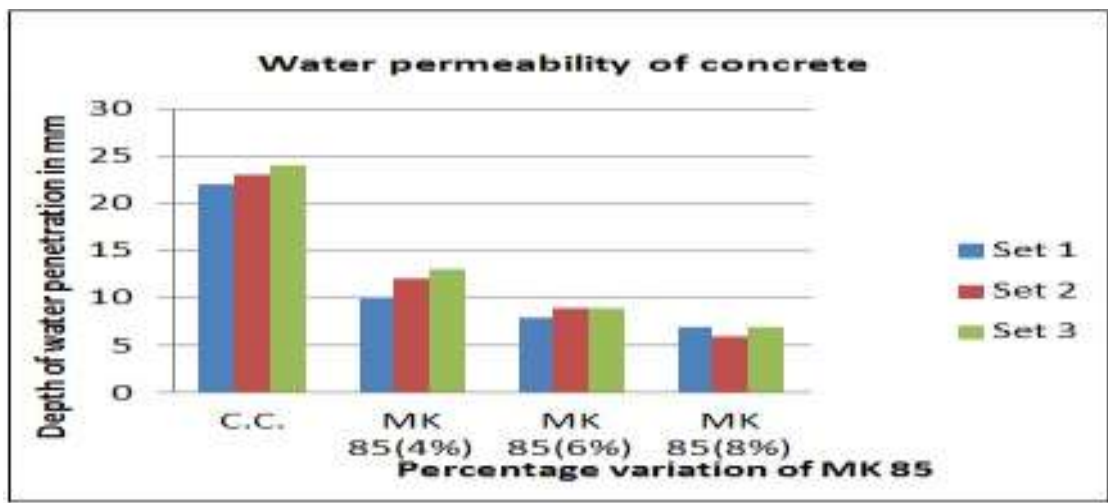

Fig. 5.2 Depth of water penetration of concrete with percentage variation of Metacem 85

\section{CONCLUSION}

1. The compressive strength of HGC increases with the replacement of metakaoline.

2. The compressive strength of HGC increases from $10.13 \%$ to $22.90 \%$ for replacement of cement from $4 \%$ to $8 \%$ of metakaoline by weight of cement.

3. The experimental results show that by adding of metakaoline water permeability depth of penetration reduces by about $71 \%$.

4. From the results, it is concluded that metakaoline clay is the good material for producing high grade concrete for any structural engineering works.

\section{References}

[1] Chitlange, M. R. Bang, R. S. Pajgade, P. S. "Strength appraisal of artificial sand as a fine aggregate in steel fibre reinforced concrete (SFRC)" ARPN Journal of Engineering and Applied Sciences, Vol, 5,NO.10,October2010,pp.34-38.

[2] Ilangovana, R. Mahendrana, N. and Nagamanib, K. "Strength and durability properties of concrete containing quarry rock dust as a fine aggregate" ARPN Journal of Engineering and Applied Sciences, ,vol. 3,No. 5, October 2008, pp.20-26

[3] Sabir, B.B., wild, S. Bai,, J. "Metakaoline and calcined clays as pozzolans for concrete: a review”, Cement and concrete research, 23 (2001) 441-454.

[4] Sadr Momtazi, A., Ranjbar, M. M. Balalaei, F. , Nemati ,R. "The effect of Iran's Metakaoline in enhancing the concrete compressive strength", Cement and concrete research, pp. 1-7

[5] Shahul Hameed, M. , Sekar, A.S.S. "Properties of green concrete containing quarry rock dust \& marble sludge powder as fine aggregate", APRN Journal of engineering \& applied sciences vol.4 no.4, (2009) pp.83-89

[6] Sravana, P. \&et.al, "Cracking behaviour of mekaolin blended high strength concrete in flexure by using crimped steel fibers" Journal of Civil Engineering Science: An International Journal,Vol. 1 No. 1-2 (January-December, 2012),pp.15-24

[7] IS: 383-1970. "Specification for coarse and Fine Aggregates from natural sources for concrete." Bureau of Indian standards, New Delhi.

[8] IS: 456-2000. "Indian Standard for code of practice for plain and reinforced concrete."

[9] IS: 516-1959(Reaffirmed 1999) Edition 1.2 (1991-07). "Indian Standard for Methods of test for strength of concrete." 